\title{
XXI. On sensitive galvanometers
}

\section{Prof. A. Gray M.A.}

To cite this article: Prof. A. Gray M.A. (1890) XXI. On sensitive galvanometers, Philosophical Magazine Series 5, 29:177, 208-211, DOI: $\underline{\text { 10.1080/14786449008619925 }}$

To link to this article: http://dx.doi.org/10.1080/14786449008619925

$$
\text { 册 Published online: } 08 \text { May } 2009 .
$$

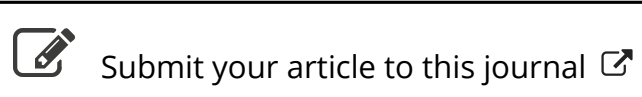

\footnotetext{
Џll Article views: 2
}

Q View related articles $\sqsubset$ 
Experiment III.-W rought-iron Bar.

\begin{tabular}{|c|c|c|c|c|c|}
\hline $\begin{array}{r}\text { Load } \\
\text { in tons. }\end{array}$ & $\begin{array}{c}n . \\
\text { Time in } \\
\text { seconds of } \\
20 \text { vibrations. }\end{array}$ & $n^{-2} \cdot 10^{5}$ & $\begin{array}{c}\text { Load } \\
\text { in tons. }\end{array}$ & $\begin{array}{c}n_{x} \\
\text { Time in } \\
\text { seconds of } \\
20 \text { vibrations. }\end{array}$ & $n^{-2} \cdot 10^{5}$ \\
\hline $\begin{array}{l}0 \cdot 0 \\
0.5 \\
0 \cdot 0 \\
0 \cdot 0 \\
0 \cdot 7 \\
1 \cdot 0 \\
0 \cdot 0 \\
1 \cdot 3 \\
1 \cdot 6 \\
0 \cdot 0 \\
2 \cdot 0 \\
0 \cdot 0 \\
2 \cdot 2 \\
0 \cdot 0 \\
2 \cdot 4\end{array}$ & $\begin{array}{l}17 \cdot 25 \\
16 \cdot 8 \\
17 \cdot 1 \\
16 \cdot 9 \\
15 \cdot 25 \\
14 \cdot 05 \\
14 \cdot 7 \\
13 \cdot 05 \\
13 \cdot 15 \\
13 \cdot 5 \\
12 \cdot 95 \\
12 \cdot 95 \\
13 \cdot 1 \\
13 \cdot 4 \\
12 \cdot 8\end{array}$ & $\begin{array}{l}336 \\
354 \\
342 \\
350 * \\
430 \\
507 \\
463 \\
587 \\
578 \\
549 \\
596 \\
596 \\
583 \\
557 \\
610\end{array}$ & $\begin{array}{l}0 \cdot 0 \\
2 \cdot 7 \\
0 \cdot 0 \\
3 \cdot 0 \\
0 \cdot 0 \\
3 \cdot 12 \\
0 \cdot 0 \\
3 \cdot 4 \\
0 \cdot 0 \\
3 \cdot 8 \\
4 \cdot 2 \\
0 \cdot 0 \\
4 \cdot 4 \\
0 \cdot 0\end{array}$ & $\begin{array}{l}13 \cdot 2 \\
13 \cdot 25 \\
12 \cdot 85 \\
13 \cdot 0 \\
13 \cdot 3 \\
12 \cdot 75 \\
14 \cdot 85 \\
12 \cdot 75 \\
15 \cdot 2 \\
12 \cdot 85 \\
13 \cdot 55 \\
16 \cdot 25 \\
13 \cdot 55 \\
15 \cdot 95\end{array}$ & $\begin{array}{l}574 \\
570 \\
606 \\
592 \\
565 \\
615 \dagger \\
453 \\
615 \\
433 \\
606 \\
545 \\
379 \\
545 \\
393\end{array}$ \\
\hline
\end{tabular}

XXI. On Sensitive Galvanometers. By Prof. A. Gray, M.A.

To the Editors of the Philosophical Magazine and Journal. Gentlemen,

T HAVE read with interest and also some surprise the remarks made by Prof. Threlfall in his paper in the Phil. Mag. for December last on the galvanometer invented by my brother and myself, and described by us in the 'Proceedings of the Royal Society,' for 1884 (vol. xxxvi.). The notes of our original observations on the sensitiveness of that instrument are I believe in the possession of my brother, who is now in the United States, and are at present therefore beyond my reach. I have, however, set up the instrument, and am now able to state some results I have obtained with it in its present state. The sensitiveness $I$ have attained is not so great as that stated in our paper ; but I feel certain, that with the same delicacy of adjustment and suspension as was formerly given to it by my brother, the former degree of sensibility would be regained.

But first as to Prof. Threlfall's statements and calculations. He says, speaking of the galvanometer of our type which he constructed, and which had a resistance of 15,852 ohms :"The test for sensitiveness was made by running a large Clark cell through 10,000 legal ohms, and a certain small 
resistance taken out of an ordinary bridge-box. The terminals of the bridge-box were coupled up through the galvanometer to a megohm.... In the final test the period of vibration of the magnet system was 80 seconds, and the resistance out of the bridge-box was $100 \mathrm{ohms}$. The E.M.F. acting through the megohm and galvanometer and $100 \mathrm{ohms}$ was therefore $\frac{100}{10100}$ Clark cells, say $\cdot 0145$ volt. The current was therefore $\frac{\cdot 0145}{116000}=1.26 \times 10^{-7}$ amperes." Lower down Prof. Threlfall says that this gave a double deflexion of 5 divisions, and that therefore the current per division was " $2.5 \times 10^{-8}$ amperes."

Now this calculation, if I understand the arrangement (and taking the statement that 0145 volt worked "through a megohm, the galvanometer, and $100 \mathrm{ohms,"} \mathrm{there} \mathrm{seems}$ no room for mistake), is evidently erroneous. The current for the 5 divisions' double deflexion was really $\frac{\cdot 0145}{1016000}$ ampere, or $1.43 \times 10^{-8}$ ampere nearly, and the current per division $2.85 \times 10^{-8}$ ampere, or $5.7 \times 10^{-8}$ ampere per division of single deflexion. Thus Prof. Threlfall, by an error in arithmetic, makes the sensibility of his instrument only about $\frac{1}{9}$ of what it was in reality, according to the data which he gives.

For this sensibility it is to be noted the period of vibration of the needle system was 80 seconds, the suspension (two silk fibres) 16 centimetres long, and the distance from the galvanometer-mirror to the scale 155 centimetres.

Prof. Threlfall then describes an instrument of another form which he constructed with the coils of the unsuccessful instrument of our form, and begins his next paper with the following statement of its sensibility:- "The galvanometer having been brought to a state of sensitiveness of 5 scale-divisions for $10^{-11}$ amperes, the measurement of the resistance of the sample of sulphur in question became a tolerably easy matter." One naturally infers from this statement that the sensibility of the galvanometer in the experiments thereafter described was $2 \times 10^{-12}$ ampere per division of deflexion. However, calculating from the table on p. 472, we find that it was really about $3 \times 10^{-11}$ ampere per division of single deflexion. If a double deflexion is meant in the statement above, this is only about $\frac{1}{7 \cdot 5}$ of the sensibility stated, or, if a single deflexion is meant, $\frac{1}{15}$ of the sensibility stated. That the instrument was working near the limit of its sensibility seems evident 
from the fact stated by the author that the zero was "always on the move."

It is to be noted that in this instrument the suspension was a quartz fibre 85 centim. long, and that the distance of the scale from the mirror appears (p. 466) to have been 3 metres. (Hence for a scale at a distance of 1 metre from the mirror the current for 1 division of single deflexion would be $9 \times 10^{-11}$ ampere.)

Thus in his comparison of the two instruments Prof. Threlfall evidently states the sensibility of his own instrument as either 15 or $7 \cdot 5$ times its real amount, and certainly makes the sensibility of the trial instrument of our form only about $\frac{1}{9}$ of what it was according to his own observations.

In my own experiments the arrangement was as follows:A circuit was made of a Daniell's cell (freshly prepared) and two resistances, one of $22,000 \mathrm{ohms}$ and the other of $100 \mathrm{ohms}$. The terminals of the galvanometer were applied at those of the resistance of $100 \mathrm{ohms}$. The galvanometer had a free period of 23 seconds, and the double deflexion produced was 88 scale-divisions each $\frac{1}{40}$ of an inch. Hence the current was nearly $1.5 \times 10^{-7}$ ampere. For one half millimetre single deflexion the current therefore was $2 \cdot 7 \times 10^{-9}$ ampere.

To compare this with Prof. Threlfall's result with the same type of instrument, we ought to reduce to a scale 1.5 metre from the mirror. The current for 1 division would then be $1.85 \times 10^{-9}$ ampere as against $5.7 \times 10^{-9}$ for Prof. Threlfall's; or, with only 23 seconds period, my instrument has 3 times the sensibility his had with a period of 80 seconds. With the latter period (and that with even a longer period, the instrument can be readily used, I am certain from our former experiments) the current would be about $\frac{1}{12}$ of that stated, or $1.5 \times 10^{-10}$ ampere per division; that is, the instrument would have about 36 times the sensibility of that made by Prof. Threlfall. The silk fibre was a little less than 3 inches long, and was by no means so fine as it might be made.

A previous set of experiments, after which the fibre was broken down, and the instrument dismounted for resuspension, gave greater sensibility. The electromotive force of the cell used was, however, in that case a little uncertain.

I ought to state that the sensibility of the instrument depends very much on its state of adjustment. As the time at ny disposal for these experiments was very limited, and I am not able to apply anything like the degree of skill which my brother used in the management of the instrument, and in the arrangement of a delicate silk-fibre suspension, the sensibility is not now so great as that which we formerly 
obtained. Were everything in its former state (and in a little time I hope to put it so), I am confident that our former estimate of the limit of practical sensibility, viz. $1 \times 10^{-11}$ ampere per division, would be found not far from the truth.

I can only rejoice if Prof. Threlfall, or anyone else, makes an instrument of a higher sensibility. I hold, however, that our instrument possesses special advantages in point of astaticism, steadiness of zero, \&c. Its principal disadvantage is its long period of free vibration owing to the large moment of inertia of the needle system. If, however, we were to construct a new instrument, this would be very grently diminished. I am, Gentlemen,

University College of N. Wales, Your obedient Servant, January 1890 .

A. Gray.

XXII. Notices respecting New Books.

Physics of the Earth's Crust. By the Rev. Osmond Frsuen, MI.A., F.G.S., \&c. Second Edition, altered and enlarged. 8vo. Pages i-xvi, 1-391. Mremillan and Co., London and New York. 1889.

THIS excellent book comprises a complete and critical digest of the various results of researches made by very many Physicists in the nature and character of observed phenomena and calculated probabilities relating to the structure and conditions of the Crust and Interior of the Earth. Its value, however, is greatly increased by the Author's own observations and calculations, especially as revised and augmented in this Second Edition. A nearly lifelong experience in Geology has afforded the Author good guidance in the application of his mathematical studies, and has been a better basis for his researches than the merely hypothetical data submitted generally to mathematicians wishing to solve such terrestrial problems as come within the limits of Physical Geology. Many diagrams and some plates are given as illustrations.

With reference to the new features of this Second Edition*, it is stated in the Preface that "possible explanations of some of the difficulties left unsolved in the first edition have since occurred to me. Investigations have also been carried on by others, which appear to strengthen and support some of the conclusions already arrived at; these needed to be followed up and embodied..... A great part of the book has been rewritten; and, while there are many additions, there are some omissions. Some portions bave been omitted because they seem uncalled for in the present state of Geological opinion; and some because they would not bave accorded with the results arrived at in the new portions. At the

* The First Edition was published in 1881. See Phil. Mag. ser. 5, vol. xv. p. 56. 